\title{
Extreme dissolved organic nitrogen fluxes in the human impacted Pamba River, Kerala, India
}

\section{S. Elizabeth David and T. C. Jennerjahn}

Leibniz Center for Tropical Marine Ecology, Fahrenheitstraße 6, 28356 Bremen, Germany

Received: 2 August 2013 - Accepted: 1 October 2013 - Published: 18 October 2013

Correspondence to: S. Elizabeth David (shilly.elizabethdavid@zmt-bremen.de) and

T. C. Jennerjahn (tim.jennerjahn@zmt-bremen.de)

Published by Copernicus Publications on behalf of the European Geosciences Union.

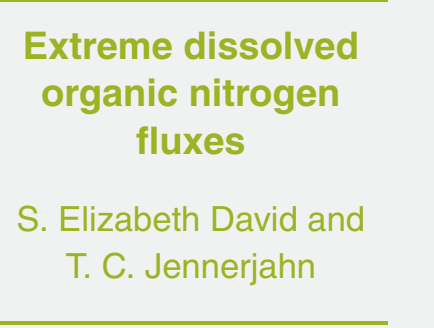

Title Page

Abstract

Conclusions

Tables

14

4

Back
Introduction

References

Figures

> I

Close

Full Screen / Esc

Printer-friendly Version

Interactive Discussion 


\section{Abstract}

Cultural eutrophication of coastal aquatic systems is a major undesired phenomenon of today, which is mainly ascribed to the application of inorganic fertilizers in agriculture. Consequently, dissolved inorganic nitrogen (DIN) is considered the major problem

5 and widely studied. However, human interventions also strongly influence the riverine dissolved organic nitrogen (DON) concentrations and fluxes. Studies of nutrient inputs from tropical river catchments are biased towards DIN, even though they account for only a portion of the total dissolved nitrogen (TDN) pool, whereas the rest is comprised of DON and has been largely ignored. The tropical Pamba River was studied because we manifold human activities in the catchment and was sampled during the south west monsoon (SWM), north east monsoon (NEM) and the pre monsoon (PM) months during 2010 to 2013 . The largest pilgrim center on earth, the Sabarimala temple, located in the upstream forest is a unique feature of the catchment. Fertilizer application, livestock farming and inadequate sewage treatment are the prevailing land use practices. The goals of this study were to (i) define cause-effect relationships by assessing the effect of various human interventions such as the pilgrims, agriculture and sewage disposal in combination with the seasonal variations in hydrology on the DON concentrations and fluxes and to (ii) quantify the inputs from respective land use segments.

The global maximum DON concentration $(29302 \mu \mathrm{M})$ was measured for the Pamba River. Pilgrim activities, high population density, agricultural and livestock farming as well as the lack of infrastructure for sanitation facilities were the cause for extremely high DON concentrations and fluxes in the plantation and settlement with mixed tree crop (SMT) segments. A DON yield of $745 \mathrm{~kg} \mathrm{ha}^{-1} \mathrm{yr}^{-1}$ was calculated for the Pamba catchment. The total DON inputs from all quantifiable sources amounted to $25514 \mathrm{~kg} \mathrm{ha}^{-1} \mathrm{yr}^{-1}$ comprising of $69 \%$ of the total Pamba DON yield. In the Pamba River, sewage is the major source of DON and the unique Sabarimala pilgrim event accounts for most of it. Nevertheless, sewage input from the rest of the densely-populated catchment is high, which is a common feature of developing countries that lack adequate
BGD

10, 16137-16171, 2013

Extreme dissolved organic nitrogen

fluxes

. Elizabeth David and

T. C. Jennerjahn

Title Page

Abstract

Introduction

Conclusions

Tables

References

Figures

14

4

Back
$>$ I

$>$

Close

\section{Full Screen / Esc}

Printer-friendly Version

Interactive Discussion 
sanitation and water technology, i.e. in South and Southeast Asia and tropical Africa. Our study shows that DON makes up a significant portion of anthropogenic nitrogen in rivers, in particular in those regions, which are, however, scarce in respective data. It underscores the need for more quantitative studies from densely-populated tropical 5 river catchments in order to improve global nitrogen budgets and the assessment of the consequences of anthropogenic nitrogen inputs into coastal aquatic systems.

\section{Introduction}

Rivers play a major role in the transport of nutrients from the terrestrial source to the receiving water bodies and are affected by both natural and anthropogenic factors. Anthropogenic factors such as high population density, deforestation, construction of dams, fertilizer usage, sewage disposal strongly alter the nature and quantity of nutrient fluxes in the river catchment. Nitrogen $(\mathrm{N})$ is one of the important nutrients for the ecosystem functioning. Human activities have greatly accelerated $\mathrm{N}$ fluxes in the terrestrial biosphere (Jordan and Weller, 1996) and fluxes of $\mathrm{N}$ cycled through aquatic 15 systems (Vitousek et al., 1997). $\mathrm{N}$ inputs to the aquatic system have increased substantially over the last century because of human activities and, the anthropogenic fixation of reactive nitrogen $\left(190 \mathrm{TgN} \mathrm{yr}^{-1}\right.$ ) exceeds that of natural biological fixation (110 $\mathrm{TgNyr}^{-1}$, Galloway et al., 2004). The enhanced supply of $\mathrm{N}$ lead to various environmental problems such as eutrophication, formation of hypoxic zones and harmful algal bloom (Rabalais, 2002; Turner et al., 2003).

Bouwman et al. (2005) estimated that on a global scale half of the riverine $\mathrm{N}$ flux is derived from anthropogenic activities. In river catchments with high population density and manifold human activities dissolved organic nitrogen (DON) can be the major $\mathrm{N}$ contributing to the total dissolved nitrogen (TDN) pool. Waste water discharge and runoff from intensive agricultural activity within watersheds are mainly responsible for the elevated DON concentrations in drainage waters (Westerhoff and Mash, 2002). Studies have shown that the source and composition of DON influence microbial re-

Extreme dissolved organic nitrogen

fluxes

. Elizabeth David and T. C. Jennerjahn

Title Page

Abstract Introduction

Conclusions

Tables References Figures

14

4

Back

Full Screen / Esc

Printer-friendly Version

Interactive Discussion $\rightarrow 1$

Close 
sponse (Seitzinger et al., 2002) and potentially contribute to coastal eutrophication and hypoxia (Glibert et al., 2006; Seitzinger and Sanders, 1997). The dissolved organic forms of nitrogen are largely ignored even though they account for a substantial proportion of the total dissolved nitrogen (TDN) in the rivers draining both undisturbed and 5 disturbed catchments (Perakis and Hedin, 2002; Lovett et al., 2000; Seitzinger et al., 2005).

Population density is one of the most commonly used parameters for expressing demographic-human impact on $\mathrm{N}$ concentrations and fluxes in rivers (Martinelli et al., 2010). $\mathrm{N}$ transport is greater for rivers draining more densely populated basins (Cole 10 et al., 1993). High $\mathrm{N}$ export rates are reported from human altered tropical watersheds (Boyer et al., 2006; Filoso et al., 2006). Even though much of the world's population live in the developing countries of the tropics, the effects of human activities on riverine $\mathrm{N}$ export are poorly understood (Martinelli et al., 2010), mainly because of a lack of data. South and Southeast Asia are among the regions with the strongest human 15 modifications of the coastal zone due to their high population density.

Large areas in central Asia including India struggle with establishing basic water services like clean drinking and sanitation (WHO/UNICEF, 2010). About $80 \%$ of the world's population is exposed to high levels of threat to water security. Regions of intensive agriculture and dense settlement show high water security and biodiversity threat of which, the Indian subcontinent is one among them (Vörösmarty et al., 2010) Rapid increase in the population and the need to meet the increasing demand for irrigation, human and industrial consumption, water resources in many parts of India are getting depleted (Bhardwaj, 2005).

Very little is known about the DON concentrations and fluxes from densely populated tropical Indian river catchments. In this study the source and transport of DON concentrations and fluxes is determined in the densely populated and human impacted Pamba River catchment. The unique feature of the Pamba River is the presence of Sabarimala temple, the largest pilgrim center in the world in its upstream catchment. Besides the large pilgrim activity, agricultural land use practices and livestock farming and sewage
BGD

10, 16137-16171, 2013

Extreme dissolved organic nitrogen

fluxes

S. Elizabeth David and

T. C. Jennerjahn

Title Page

Abstract

Introduction

Conclusions

Tables

References

Figures

14

4

Back

Full Screen / Esc

Printer-friendly Version

Interactive Discussion 
effluents are the major anthropogenic activities in the Pamba catchment. The main objective of the study is to define direct cause-effect relationships by understanding the effect of various human interventions such as the pilgrims, agriculture and sewage disposal in combination with the seasonal variations in hydrology on the dissolved or-

5 ganic nitrogen concentrations and fluxes in the Pamba catchment. A segment wise DON load and yield was calculated to assess the impacts caused by the individual human interventions into the river.

\section{Materials and methods}

\subsection{Study area}

10 The study area is located in the south west coast of India in the state of Kerala. The Pamba is one of the 41 west flowing rivers in Kerala originating from the Western Ghat mountains in the east. The Pamba River has a length of $176 \mathrm{~km}$ and a total basin area of $2235 \mathrm{~km}^{2}$. The river originates from Pulachimala in the Western Ghats at an altitude of $1650 \mathrm{~m}$ and flows westwards and debouches in to the Vembanad estuary with an 15 annual discharge of $3.9 \mathrm{~km}^{3}$.

The Pamba catchment has a population density of 916 individuals $\mathrm{km}^{-2}$ making up a total of 900000 inhabitants (Census of India, 2011). The climate is dominated by two monsoons i.e., south west monsoon (SWM) and north east monsoon (NEM) followed by a dry pre monsoon (PM) season. $60 \%$ of the total precipitation is obtained during the SWM from mid May/beginning of June to August and $30 \%$ during the NEM from October to December and $10 \%$ during the PM from January to mid May (Fig. 1).

The Pamba catchment can be categorised into three topographically distinct regions that are representative of different land use practices i.e., the upstream forest region, midstream settlement with mixed tree crops (SMT) region and downstream paddy cultivable region. Major land use categories in the Pamba basin include forest, comprising of $44 \%$ of the total land area. Two reservoirs - Pamba and Kakki - with a storage
BGD

$10,16137-16171,2013$

Extreme dissolved organic nitrogen

fluxes

S. Elizabeth David and T. C. Jennerjahn

Title Page

Abstract Introduction

Conclusions

Tables References Figures

14

4

Back

Full Screen / Esc

Printer-friendly Version

Interactive Discussion $\rightarrow 1$

Close 
capacity of $493.5 \times 10^{6} \mathrm{~m}^{3}$ are located in the dense forest region and cover $0.9 \%$ of the total land area. Sabarimala temple, the largest pilgrimage centre in the world is situated in the upstream catchment. During the pilgrim season i.e., from November to January, about 50 to 60 million pilgrims visit the temple every year (BusinessLine, .Forest plantations such as tea, teak, rubber, cardamom and eucalyptus occupy $14 \%$ of the total land area. Settlement area together with mixed crops such as vegetables, banana, tapioca, coconut, mango, jack and cashew trees comprises the midstream reaches. Settlement with mixed tree crop (SMT) area covers $14 \%$ of the total land area. Paddy cultivation is the main land use practice in the downstream reaches together with a small SMT area. Compared to the upstream reaches, the mid- and downstream reaches have a higher population density (Table 1, Fig. 2).

The Pamba catchment was divided into 8 segments for the segment wise load and yield estimation. Segments were categorized based on land use and on hydrologic units (Fig. 2). The upstream forest area is subdivided into 3 regions i.e., dense forest, temple and plantation regions, respectively. Segment I comprises of minimally disturbed dense forest region. The temple region is represented by segment II. Segment III represents mainly the forest area with mixed plantation. Segment IV comprises mainly the forest and rubber plantation along with a small settlement area. Segment $V$ is the main confluence point of the above segments and represents mainly rubber plantation with a small SMT region. The Malakkara gauging station divides segments VI and VII. Segment VI represents SMT along with a small area of rubber plantation, while SMT and paddy cultivation is the main land use in segment VII. Land use of segment VIII is similar to that of segment VII and was categorized as a different segment because of the merging of the adjacent Achankovil and Manimala rivers with the Pamba River forming an inland deltaic region. Individual river contributions were difficult to distinguish in segment VIII.
BGD

$10,16137-16171,2013$

Extreme dissolved organic nitrogen

fluxes

. Elizabeth David and

T. C. Jennerjahn

Title Page

Abstract

Introduction

Conclusions

Tables

References

Figures

14

4

Back

Full Screen / Esc

Printer-friendly Version

Interactive Discussion 


\subsection{Sampling and analysis}

16 locations were sampled along the river course from the upstream forest to the estuarine mouth. Monthly sampling was done for 9 months during 2010 to 2012 to cover the SWM, NEM and PM seasons. The sampling locations were selected based on land use

5 and watershed characteristics. The samples were grouped based on the land use categories as undisturbed forest (location 1), temple (location 2 to 4), plantation (location 5 to 8), SMT (location 9 to 11) and paddy (location 12 to 16) areas, respectively.

For the total dissolved nitrogen (TDN) analysis $10 \mathrm{~mL}$ of water were filtered through single use Sartorius syringe filters into a glass vial and fixed with $13 \mu \mathrm{L}$ of $20 \%$ phosphoric acid. Samples were stored frozen until analysis. Total dissolved nitrogen (TDN) was determined in a Shimadzu TOC-VCPH Total Organic Carbon Analyzer with a TNM-1 Total Nitrogen Measuring Unit combusting at $720^{\circ} \mathrm{C}$. The detection limit was $0.32 \mathrm{mg} \mathrm{L}^{-1}$. Random samples ranging from low to high TDN concentrations were analyzed again in the Institute of Biogeochemistry and Marine chemistry, University of

15 Hamburg using TOC-V CSH/CSN Total Organic Carbon Analyzer. The detection limit was $0.29 \mathrm{mg} \mathrm{L}^{-1}$. The coefficient of variation of the analysis was $<1.5 \%$. Dissolved inorganic nitrogen (DIN) were analyzed using a continuous flow analyzing system (Skalar $\mathrm{SAN}++$ System). Nitrate + nitrite $\left(\mathrm{NO}_{\mathrm{x}}^{-}\right)$and nitrite $\left(\mathrm{NO}_{2}^{-}\right)$were determined spectrophotometrically and ammonium $\left(\mathrm{NH}_{4}^{+}\right)$fluorometrically (Grasshoff, 1999). DIN was calculated by summing up $\mathrm{NO}_{3}^{-}, \mathrm{NO}_{2}^{-}$and $\mathrm{NH}_{4}^{+}$. The relative standard deviation of each method was $<3.3 \%$. Determination limits were $0.075 \mu \mathrm{M}, 0.035 \mu \mathrm{M}$ and $0.051 \mu \mathrm{M}$ for $\mathrm{NO}_{x}, \mathrm{NO}_{2}$ and $\mathrm{NH}_{4}$, respectively. Dissolved organic nitrogen (DON) was calculated as TDN - DIN.

\subsection{Calculation of segment wise river DON budgets}

25 For the budget calculation, the exit location of each segment (end location) was selected. Discharge data for the Malakkara gauging station were obtained from the Central Water Commission (CWC), Government of India. Annual flow at the gauging station

Extreme dissolved organic nitrogen

fluxes

S. Elizabeth David and T. C. Jennerjahn

Title Page

Abstract

Conclusions

Tables

Figures

14

4

Back

Full Screen / Esc

Printer-friendly Version

Interactive Discussion $\rightarrow 1$

Close 
was calculated based on the monthly discharge data. Discharge per cubic kilometer and DON load and yield of the river were calculated using the following equations.

Discharge in $\mathrm{km}^{3} \mathrm{~km}^{-2}(Q)=Q_{\mathrm{M}} / A_{\mathrm{M}}$

where $Q_{M}=$ discharge at the Malakkara gauging station; $A_{M}=$ catchment area till 5 Malakkara gauging station

Discharge per segment $\left(Q_{\mathrm{S}}\right)=A_{\mathrm{s}} \times Q$

where $A_{\mathrm{s}}=$ segment area $\left(\mathrm{km}^{2}\right)$

DON load $\left(\mathrm{tyr}^{-1}\right)=C \times Q_{\mathrm{S}} / 1000$

where $C=$ average concentration of the end location $\left(\mathrm{mgL}^{-1}\right)$

DON yield $\left(\mathrm{kg} \mathrm{ha}^{-1} \mathrm{yr}^{-1}\right)=\mathrm{DON}$ load $/ A_{\mathrm{s}} \times 100$

Catchment area is the most important discharge determining factor as has been observed in a case study from Kerala. There, annual water discharge correlated significantly with catchment area ( $r=0.78$; Chattopadhyay and Chattopadhyay, 2009). Following this approach we calculated a discharge $(Q)$ of $0.2 \mathrm{~km}^{3} \mathrm{~km}^{-2}$ of catchment area 15 for the Pamba River, which we then used for segment wise nutrient budget calculations. In the absence of robust discharge data from specific land use segments, this method is perhaps the best approximation.

\subsection{Statistics}

Data were statistically analyzed using the SigmaPlot 12.3 software. A one-way anaysis of variance (ANOVA) was performed to test the seasonal and spatial variations. Linear regression analysis was done on log-transformed data to evaluate the correlations between population density, sewage discharge and DON yield.

Extreme dissolved organic nitrogen

fluxes

S. Elizabeth David and T. C. Jennerjahn

Title Page

Abstract Introduction

Conclusions

Tables Figures

14

4

Back

Close

Full Screen / Esc

Printer-friendly Version

Interactive Discussion 


\section{Results}

DON concentrations ranged from 36 to $29302 \mu \mathrm{M}$ with an average concentration of $5940 \mu \mathrm{M}$ in the river during the whole study period. Both spatial and temporal variations in DON concentrations were observed (Fig. 3). Location 1 in the upstream forest 5 region exhibited comparatively low values with an average concentration of $371 \mu \mathrm{M}$. Concentrations were found to be high throughout the catchment, particularly in the temple, plantation and SMT segments. The maximum concentration of $29302 \mu \mathrm{M}$ was observed at location 2 during the pilgrim months. In the temple locations DON concentrations varied widely before, during and after the pilgrim event. Concentration was 作 the event in November and decreased to $64 \mu \mathrm{M}$ after the event in April in location 3. When compared to other segments, values were high in the plantation and SMT segments during the NEM. The second highest concentration of $28724 \mu \mathrm{M}$ was observed in location 6 in the plantation segment. Concentrations were high in the agricultural dominated downstream segments, particularly in the paddy cultivated segments during the PM, except for high values in the temple locations during January and February. A maximum concentration of $21014 \mu \mathrm{M}$ was observed in location 14 during March. In location 13 during April a maximum value of $25862 \mu \mathrm{M}$ was displayed and was high compared to other locations. A maximum value of $11648 \mu \mathrm{M}$ was observed in location 10 during the SWM. Significant seasonal variations in concentration were observed between NEM and PM months $(p<0.050)$.

The minimum annual DON load of the Pamba River of $2244 \mathrm{t}$ was observed in segment I. A maximum load of $84929 \mathrm{t}$ was contributed from segment IV, followed by $66982 \mathrm{t}$ from segment III and $43398 \mathrm{t}$ from segment II, respectively. A minimal loading of $13421 \mathrm{t}$ was observed at Segments VII, compared to the other agricultural segments. Similar to the load, a minimum DON yield of $90 \mathrm{~kg} \mathrm{ha}^{-1} \mathrm{yr}^{-1}$ was observed at segment I. The highest yield of $1976 \mathrm{~kg} \mathrm{ha}^{-1} \mathrm{yr}^{-1}$ was observed at segment II, followed by yields of $1863 \mathrm{~kg} \mathrm{ha}^{-1} \mathrm{yr}^{-1}$ and $1818 \mathrm{~kg} \mathrm{ha}^{-1} \mathrm{yr}^{-1}$ in segments III and V, respectively. In the down-

16145
BGD

10, 16137-16171, 2013

Extreme dissolved organic nitrogen

fluxes

S. Elizabeth David and

T. C. Jennerjahn

Title Page

Abstract

Introduction

Conclusions

Tables

References

Figures

14

4

Back

Close

Full Screen / Esc

Printer-friendly Version

Interactive Discussion 
stream segments $\mathrm{VI}$ and VIII, DON yield exhibited a decreasing trend towards the river mouth (Table 2).

A full segment wise quantification of DON inputs per land use is not possible without being able to quantify losses during transport. Because of this missing loss term

5 a simple subtraction of the DON load of an upstream segment from that of the next downstream segment can in some instances result in a negative load. Therefore, absolute quantification was possible only for segments I, II and IV. Nutrient quantification of segment II, i.e. from pilgrims was calculated because of very low nutrient input from the undisturbed segment I. Segment IV was not influenced by the upstream segments 10 I and II and high nutrient inputs therein were from the fertilizer inputs and settlements. In these cases, the respective numbers given for the downstream segments can be considered semi-quantitative only while, absolute numbers were given for the undisturbed, temple and plantation segments. Nevertheless, segment wise load and yield calculations are the best estimates possible and provide important insights into DON budgets in human-impacted Pamba river catchment.

A socio-economic survey was conducted among farmers from the paddy, SMT and rubber plantation regions to collect information about the quality, quantity and time of fertilizer application in the agricultural fields. Factamphose, urea and potash were the common synthetic NPK fertilizers applied in the fields. The NPK fertilizer loads in the land use segments were calculated by multiplying the rate of fertilizer application with the respective land area. Detail survey results are described in (Elizabeth David et al., 2013). Annual synthetic $\mathrm{N}$ fertilizer input in the paddy, SMT and rubber plantation regions were $3313 \mathrm{t}, 4885 \mathrm{t}$ and $1644 \mathrm{t}$, respectively. Of the total $\mathrm{N}$ input, $45 \%$ was composed of urea and amounting to $44.3 \mathrm{~kg} \mathrm{ha}^{-1} \mathrm{yr}^{-1}$. Agricultural land occupies $37 \%$ of the total land area in the Pamba catchment. When normalized to the whole catchment area, the total synthetic $\mathrm{N}$ fertilizer input was $44 \mathrm{~kg} \mathrm{ha}^{-1} \mathrm{yr}^{-1}$, of which $20 \mathrm{~kg} \mathrm{ha}^{-1} \mathrm{yr}^{-1}$ was urea.

Extreme dissolved organic nitrogen

fluxes

S. Elizabeth David and

T. C. Jennerjahn

Title Page

Abstract Introduction

Conclusions

Tables

References

Figures

14

>

4

Back

Close

Full Screen / Esc

Printer-friendly Version

Interactive Discussion 


\section{Discussion}

Both the concentrations and loads of nitrogen in the Pamba catchment are dominated by dissolved organic nitrogen (99\%). The reasons for the high DON values are discussed below.

\section{4.1 Impacts from the undisturbed land use area}

DON concentrations and yield in the undisturbed forested segment I was low compared to the values from the human impacted segments (Fig. 3, Table 2). The yield in segment $I$ in the Pamba catchment was much higher than in other forested catchments in the world.

10 DON in the stream water of forested regions can originate from throughfall, leaching, decomposition of litter and soil organic matter, plant exudates, and the waste products of macro- and microorganisms (Campbell et al., 2000). A study conducted in the wet tropical La Selva forest in Costa Rica quantified the DON flux in the throughfall $\left(9 \mathrm{kgha}^{-1} \mathrm{yr}^{-1}\right)$, litter leachate $\left(13 \mathrm{kgha}^{-1} \mathrm{yr}^{-1}\right)$ and in the soil solution $(0.4$ to $153 \mathrm{kgha}^{-1} \mathrm{yr}^{-1}$ ) (Schwendenmann and Veldkamp, 2005). Another study conducted in three subtropical forests in South China under high air pollution quantified the DON flux in precipitation $\left(17.8 \mathrm{~kg} \mathrm{ha}^{-1} \mathrm{yr}^{-1}\right.$ ), throughfall (14.6 to $20.1 \mathrm{~kg} \mathrm{ha}^{-1} \mathrm{yr}^{-1}$ ) and soil solution (6.5 to $16.9 \mathrm{~kg} \mathrm{ha}^{-1} \mathrm{yr}^{-1}$ ), respectively. DON accounts for 28 to $40 \%$ of the total dissolved $\mathrm{N}$ (Fang et al., 2008). The climate is warm and humid with a mean annual precipitation and humidity of $1927 \mathrm{~mm}$ and $80 \%$, respectively.

In the Pamba catchment, the climate is warm and humid. The annual average precipitation rate is higher $(2643 \mathrm{~mm}$, Central Water Commission) than reported for the subtropical forests in South China. Dense forest cover comprising of organic rich forest loam soil and heavy precipitation rates during monsoon months are characteristic features of segment I. Taking into account the climate conditions, segment I in the Pamba catchment is similar to that of the subtropical South China forest. Natural biological nitrogen fixation (BNF) can be an important DON source in the forest segment,

Extreme dissolved organic nitrogen

fluxes

. Elizabeth David and T. C. Jennerjahn

Title Page

Abstract Introduction

Conclusions

Tables References Figures

14

4

Back

Close

Full Screen / Esc

Printer-friendly Version

Interactive Discussion 
as for instance, in the Latin America, Africa and Oceania regions, of the total $\mathrm{N} 85 \%$ was comprised by BNF (Galloway et al., 2004; Boyer et al., 2006). Due to a lack of field data, the DON from the abovementioned specific sources cannot be quantified. Missing data from other regions with a comparable environmental setting even did not

5 allow an estimate for BNF. It is concluded that the major DON in this forest segment is from throughfall, leaching and decomposition of litter and soil organic matter and plant exudates as observed for the South China forests.

\subsection{Effect of pilgrim activity}

Dissolved organic nitrogen concentrations were extremely high in the temple locations 10 (Fig. 3) during the pilgrim season. Before visiting the Sabarimala shrine pilgrims conducted ritualistic bathing in the Pamba River. Various activities such as usage of soap, discarding clothes and plastics, urinating and, in many instances defecating on the river banks were practiced. Similar activities were also reported in different parts of the Ganges River in North India, where millions of people gather for the famous Kumbh fes15 tival. In 2010, this event was taken place in the Haridwar city in Uttarakhand State and 41.6 million pilgrims took ritualistic bathing in the river thereby, leading to water quality deteriorations (Tyagi et al., 2012). Biological oxygen demand (BOD) and total suspended solid (TSS) concentrations varied before, during and after the event. Before the event, the mean BOD and TSS concentrations were $2 \pm 0.4 \mathrm{mg} \mathrm{L}^{-1}$ and $17 \pm 3.7 \mathrm{mg} \mathrm{L}^{-1}$. 20 During the event the values increased up to $6 \pm 2.9 \mathrm{mg} \mathrm{L}^{-1}$ and $30 \pm 9.7 \mathrm{mg} \mathrm{L}^{-1}$ and, after the event the values decreased considerably to $2 \pm 0.4 \mathrm{mg} \mathrm{L}^{-1}$ and $19 \pm 1.9 \mathrm{mg} \mathrm{L}^{-1}$, respectively. High numbers of fecal coliforms were observed during the event. Dissolved oxygen (DO) and $\mathrm{pH}$ varied slightly before, during and after the bathing event in the Ganges River. In addition to the bathing event, the offering of milk, curd, sugar, flowers, 25 ashes of departed ones, body hairs etc into the river resulted in water quality deteriorations during the event (Tyagi et al., 2012).

In the Pamba temple locations, $\mathrm{DO}$ and $\mathrm{pH}$ values varied considerably before, during and after the pilgrim event. Before the event the average $\mathrm{DO}$ and $\mathrm{pH}$ values were

Extreme dissolved organic nitrogen

fluxes

S. Elizabeth David and T. C. Jennerjahn

Title Page

Abstract Introduction

Conclusions

Tables References Figures

14

4

Back

Close

Full Screen / Esc

Printer-friendly Version

Interactive Discussion $\rightarrow$

-

(ctive Discussion 
$5.8 \pm 1 \mathrm{mg} \mathrm{L}^{-1}$ and $7.3 \pm 1$. Values decreased to $3.5 \pm 1 \mathrm{mg} \mathrm{L}^{-1}$ and $7.1 \pm 0$ during, and increased to $4.2 \pm 1 \mathrm{mgL}^{-1}$ and $7.1 \pm 1$ after the event, respectively. Similarly, the dissolved inorganic nitrogen (DIN) values also displayed variations before, during and after the Sabarimala pilgrim event (Elizabeth David et al., 2013). The same was observed for 5 the DON where, the value was two to three orders of magnitude higher $(20201 \mu \mathrm{M})$ during the event than before $(429 \mu \mathrm{M})$ and after $(64 \mu \mathrm{M})$ it (Fig. 3).

Organic $\mathrm{N}$ content in faeces and urine of an adult person is $\sim 1.5$ and $1.7 \mathrm{~g}$ per day, respectively, and $\mathrm{N}$ in the form of ammonia and urea in urine of an adult person is $10.5 \mathrm{~g}$ per day (Painter and Viney, 1959). Urea is the main organic $\mathrm{N}$ compound of it 10 amounting to $85 \%$ (GeigyScientificTables, 1981). Approximately, 555000 pilgrims visit the temple per day during the pilgrim season. Pilgrim activities are mainly concentred in about $10 \mathrm{~km}^{2}$ area downstream of the Sabarimala shrine. DON flux during the pilgrim season was calculated by multiplying the individual organic $\mathrm{N}$ load in human wastes per day with the total number of pilgrims per day in the $10 \mathrm{~km}^{2}$ area. A DON flux of $15606 \mathrm{~kg} \mathrm{ha}^{-1}$ was calculated in the temple area where pilgrims conducted bathing and associated activities.

High DON values were also observed in the downstream temple locations in the plantation segment, particularly in the NEM. Because of the huge crowd many pilgrims go to downstream temple locations for bathing before visiting the shrine. The 20 wash off of nutrients from the human impacted locations upstream together with the anthropogenic activities in the location itself resulted in the second highest DON concentration in location 6 . Hence, the gathering of millions of people for the religious event and associated activities in the upstream catchment not only had an impact in locations therein, but in the downstream segments as well. Therefore, the Sabarimala 25 pilgrim event is considered as the major cause for the extremely high DON flux in the Pamba River.

BGD

$10,16137-16171,2013$

Extreme dissolved organic nitrogen

fluxes

. Elizabeth David and

T. C. Jennerjahn

Title Page

Abstract Introduction

Conclusions

Tables References Figures

14

4

Back

Full Screen / Esc

Printer-friendly Version

Interactive Discussion 


\subsection{Impacts due to agriculture}

DON accounts for a high percentage (99\%) of TDN concentrations in the agricultural dominated segments in the Pamba catchment. When estimating segment wise, DON yield was high in the SMT and agricultural dominated segments (III to VI). A study 5 conducted in 7 contrasting agricultural land use types in England, Whales and Greece comprised an average DON of $57 \pm 8 \%$ of the TDN pool in soil (Christou et al., 2005). Another agricultural dominated catchment in South-East Spain (Lorite-Herrera et al., $2009)$ accounted the DON percentage in the ground water $(98.5 \%)$ and river water $(97.2 \%)$ of the TDN pool and having concentrations ranging from 7 to $2442 \mu \mathrm{M}$ and 10450 to $1414 \mu \mathrm{M}$, respectively. When compared with the Pamba catchment, the \% composition of DON in south-east Spain catchment was found similar (99\%), while the concentrations (36 to $29302 \mu \mathrm{M}$ ) were in a much lower range.

Generally, in the agricultural fields urea is often applied when the rainfall is anticipated and about 3 to $5 \%$ of the surface applied urea can be lost via runoff (Glibert et al., 2006). Following the general trend, fertilizer is applied before the onset of the SWM and NEM except for the paddy cultivated area, because this area in the Pamba catchment lies below sea level and usually gets flooded during heavy rains in the monsoon months. To avoid this natural calamity, paddy cultivation normally begins during the end of NEM, i.e. during November. Fertilizer application starts by then and continues in the PM.

In the agricultural dominated Guadalquivir catchment, urea was applied at a rate of $350 \mathrm{~kg} \mathrm{ha}^{-1}$ (Lorite-Herrera et al., 2009). When compared to the Pamba catchment, the application rate was about 8-fold higher whereas, the DON yield in the Guadalquivir catchment was orders of magnitude lower $\left(2 \mathrm{kgha}^{-1}\right)$. In the Guadalquivir catchment sewage is not a significant source (Lorite-Herrera and Jiménez-Espinosa, 2008). Taking into account the timing of fertilizer application, about 3 to $5 \%$ of the surface applied urea can be lost via runoff in the Pamba catchment. Considering the total amount of urea fertilizer applied in the agricultural fields $\left(20 \mathrm{~kg} \mathrm{ha}^{-1} \mathrm{yr}^{-1}\right)$, probably less than
BGD

$10,16137-16171,2013$

Extreme dissolved organic nitrogen

fluxes

. Elizabeth David and

T. C. Jennerjahn

Title Page

Abstract

Introduction

Conclusions

Tables

References

Figures

14

4

Back

Full Screen / Esc

Printer-friendly Version

Interactive Discussion 
$1 \mathrm{kgha}^{-1} \mathrm{yr}^{-1}$ is lost via surface runoff, whereas the rest is taken up by the crops or retained in the soil in the Pamba catchment. Thus it is likely that urea application does not contribute significantly to the extremely high DON in the agriculture dominated segments in the Pamba catchment.

5 Livestock excretions is another potential DON source in the agricultural dominated segments in the Pamba catchment. Livestock wastes contain extremely high DON concentrations (Bristow et al., 1992). The $\mathrm{N}$ content in urine of grazing animals normally ranges from 8 to $15 \mathrm{~g} \mathrm{~L}^{-1}$. Urine increases the $\mathrm{pH}$ of the soil due to the hydrolysis of urea (Haynes and Williams, 1993) and can considerably increase the DON and DOC 10 together with other compounds in the soil solution (Shand and Coutts, 2006). The N concentrations in the soil exceed the ability of plants and soil organisims to utilise that $\mathrm{N}$ for growth (Hoogendoorn et al., 2010). The stocking rates of animals per hectare have a strong effect on the amount of urine deposited and subsequent DON losses (van Kessel et al., 2009). The soil surface nitrogen content was quantified for different 15 states of India for the period 2000 to 2001 (Prasad et al., 2004). According to this study, livestock manure constituted a major percentage of total $N$ inputs $(44 \%)$ in the agricultural regions. When compared to the other Indian states, $\mathrm{N}$ input from livestock excretions was high in Kerala thereby, comprising of $616.4 \mathrm{~kg} \mathrm{ha}^{-1}$. In the Pamba catchment, cattle and fowls are abundant (as per field observation) and is in accordance with the 20 findings of Prasad et al. (2004). Farmyard manure is commonly applied together with synthetic fertilizer in the catchment and amounted to $553 \mathrm{tyr}^{-1}$ of $\mathrm{N}$ in the agricultural region (Elizabeth David et al., 2013).

The total amount of $\mathrm{N}$ leached from livestock urine varies between 18 to $58 \%$ of the $\mathrm{N}$ applied, depending on the soil texture (Clough et al., 1998). Taking into account 25 the abovementioned range, in the Pamba catchment the DON leaching loss from livestock excretions can range from 111 to $386 \mathrm{~kg} \mathrm{ha}^{-1} \mathrm{yr}^{-1}$. For example, the DON loss from grazed grassland catchments in Northern Ireland ranged from 5 to $24 \%$ of the total $\mathrm{N}$ and the soil therein is sandy-clay-loam (Watson et al., 2000). The soil in the Pamba catchment is also sandy-clay-loam. Therefore, taking into account the soil tex-

BGD

$10,16137-16171,2013$

Extreme dissolved organic nitrogen

fluxes

S. Elizabeth David and

T. C. Jennerjahn

Title Page

Abstract Introduction

Conclusions

Tables

References

Figures

14

4

Back

Full Screen / Esc

Printer-friendly Version

Interactive Discussion
$>$ I
Close 
ture, a maximum of $24 \%$ DON loss from livestock excretions is possible. The DON loss calculated via this source is $148 \mathrm{~kg} \mathrm{ha}^{-1} \mathrm{yr}^{-1}$ and makes up a significant portion of the total DON input in the Pamba River (Table 3).

Variations in the DON loading were observed in the agricultural dominated segments 5 (III to VIII) in the Pamba River. DON loading in the agricultural dominated segments was lower during PM compared to the SWM and NEM (Fig. 4). The DON loads were high in segment II and III because of the maximum pilgrim activity during the PM. The high loads were not transported to downstream segments due to low flow conditions, consequently resulting in low DON load in the mid- and downstream agricultural dominated 10 segments.

The main drivers leading to DON loss in agricultural soils are precipitation and irrigation events and their frequencies (van Kessel et al., 2009). $70 \%$ of the total precipitation is received during the SWM in the Pamba catchment. High DON loading at that time is due to the washoff of agricultural soils as well as the $\mathrm{N}$ leaching via livestock excre15 tions during high water flow conditions. In addition to this, heavy precipitation during the onset of SWM transports the DON that accumulated in the upstream temple segment during low flow conditions after the pilgrim event to the mid- and downstream segments. When compared to the SWM, the DON concentrations and load in the plantation and SMT segments during the NEM were higher which is mainly due to the excess nutrient loads from the pilgrim season as well as the $\mathrm{N}$ leaching loss via livestock excretions.

When comparing the segment wise annual yield, DON decreased towards the river mouth from segment VI, i.e. the yield was lower in the paddy cultivated segments VII and VIII. Rice paddies favor denitrification in the wet climate (Borbor-Cordova et al., 2006). Urea applied in the field can be hydrolyzed to nitrate and under water logged conditions due to microbial activity denitrification is enhanced, leading to the $\mathrm{N}$ loss thereby, resulting in low yields in the paddy cultivated segments in the Pamba catchment.

Most biological nitrogen fixation in terrestrial systems occurs in tropical regions (Galloway et al., 2008). River DON can also be derived from natural sources such as
BGD

10, 16137-16171, 2013

Extreme dissolved organic nitrogen

fluxes

. Elizabeth David and

T. C. Jennerjahn

Title Page

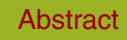

Introduction

Conclusions

Tables

References

Figures

14

4

Back $\rightarrow$ I

Full Screen / Esc

Printer-friendly Version

Interactive Discussion 
biological nitrogen fixation from agricultural crops (BNF-agr, Galloway et al., 2004). In the tropical Piracicaba basin in Brazil, the input from BNF-agr accounted for $14.5 \mathrm{kgha}^{-1} \mathrm{yr}^{-1}$ (Filoso et al., 2003). For both the Oder and Vistula watersheds of Poland, the input from BNF-agr amounted to $16 \mathrm{~kg} \mathrm{ha}^{-1} \mathrm{yr}^{-1}$ each. In the Indian agricul-

5 tural area, $\mathrm{N}$ fixation made up to $17.1 \mathrm{~kg} \mathrm{ha}^{-1} \mathrm{yr}^{-1}$ (Prasad et al., 2004). It is therefore conceivable that the input from BNF-agr in the agricultural dominated Pamba watershed adds significantly to the total DON load of the Pamba River. Atmospheric organic nitrogen (AON) deposition can also be a potential DON source in the Pamba catchment. Urea, amino acids, animal husbandary operations, agricultural and biomass 10 burning accounts for the AON deposition, and comprise one third of the total $\mathrm{N}$ deposition (Neff et al., 2002). According to Galloway et al. (2008) the total N deposition rate for Kerala falls into the range $10-20 \mathrm{~kg} \mathrm{ha}^{-1} \mathrm{yr}^{-1}$. Taking one third of this value according to Neff et al. (2002), results in about $5 \mathrm{kgha}^{-1} \mathrm{yr}^{-1}$ of AON being deposited in the Pamba catchment. In agricultural dominated catchments, where inorganic fertilizers are applied on a regular basis, root exudation and turnover from different vegetation can also be a source of DON (Christou et al., 2006). Thus the impact of agriculture in the Pamba catchment in terms of livestock farming is more significant compared to the fertilizer application in the fields thereby, contributing a major portion to the total DON input in the Pamba River.

\subsection{Impacts due to domestic waste disposal}

The delivery of waste water and organic fertilizer via surface runoff represent a potential direct source of DON to streams in agricultural watersheds (Pellerin et al., 2006). A very common phenomenon in the Pamba catchment is that many houses on the banks have their sewage pipes turned to the river thereby, facilitating flow of domestic sewage into it. Domestic sewage includes waste water from bathing, washing, food preparation and from dish washing along with faeces and urine. On average, organic $\mathrm{N}$ in domestic sewage per person per day is $3.4 \mathrm{~g}$ and ammonia and urea $\mathrm{N}$ comprises

Extreme dissolved organic nitrogen

fluxes

. Elizabeth David and T. C. Jennerjahn

Title Page

Abstract Introduction

Conclusions

Tables

References

Figures

14

4

Back

Full Screen / Esc

Printer-friendly Version

Interactive Discussion $\rightarrow$

Close

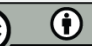


$5.3 \mathrm{~g}$, respectively (Painter and Viney, 1959). In waste water approximately $80 \%$ of the total $\mathrm{N}$ is urea (Hanson and Lee, 1971).

Population density increases from the upstream to the downstream segments in the Pamba catchment. Domestic sewage inputs in these segments were high because, 5 more people live near the river and the population density on a micro-scale is more than in the other parts of the catchment. Annual domestic sewage $\mathrm{N}$ inputs in the Pamba catchment were calculated by multiplying the population density per square kilometer with the amount of domestic sewage $\mathrm{N}$ produced per person per day. Approximately, $26 \mathrm{~kg} \mathrm{ha}^{-1} \mathrm{yr}^{-1}$ of $\mathrm{N}$ was introduced into the river via domestic sewage inputs and was 10 an order of magnitude higher than the other human impacted world rivers (Fig. 5b). Domestic sewage inputs despite being high, the values does not balance the high DON yields in the mid-and downstream segments of the Pamba River. DON yields in these segments were much lower than for the temple segments. This indicates that the domestic sewage inputs from the settlement region were not high as the inputs from the pilgrims (Fig. 5c). Therefore, the yields in these segments are the cumulative effect of the whole upstream river catchment. DON uptake by phytoplankton and bacteria might be the reasons for the much lower DON yield in the paddy segments in contrast to high domestic sewage inputs due to high population density therein.

Water resource management is a major challenge in India and the country has high incident and adjusted human water security threat. The semi-arid climate and high seasonal water availability coupled with pollution and water consumption by the large and growing population resulted in high incident threat whereas, the investment in technology and infrastructure to improve human access to water resources is low thereby leading to adjusted human water security threat in India. The investment level in water resource infrastructure varies among parts of the country, but is rarely high, leaving most of the country with high adjusted threat relative to other regions in the world (Vörösmarty et al., 2010) The lack of infrastructure, in particular for the sewage collection and treatment, is most probably the reason that the sewage $\mathrm{N}$ in the Pamba

Extreme dissolved organic nitrogen

fluxes

S. Elizabeth David and

T. C. Jennerjahn

Title Page

Abstract Introduction

Conclusions

Tables

References

Figures

14

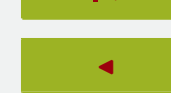

$\rightarrow 1$

4

Back

Close

Full Screen / Esc

Printer-friendly Version

Interactive Discussion 
catchment was an order of magnitude higher than in other human impacted catchments (Fig. 5).

\subsection{Dissolved organic nitrogen budgets in the global context}

The Pamba River transported $128061 \mathrm{t}$ of DON to the receiving Vembanad estuary, 5 annually. The Pamba DON yield amounted to $745 \mathrm{~kg} \mathrm{ha}^{-1} \mathrm{yr}^{-1}$ and was two orders of magnitude higher compared to results from the NEWS (Global Nutrient export from Watersheds, Fig. 5) DON model (Harrison et al., 2005). The DON yield increased linearly with population density $\left(r^{2}=0.786, p<0.001\right.$, Fig. $\left.5 a\right)$ in the Pamba catchment. Without the Pamba data, the DON yield was only weakly correlated with population density in other world river catchments $\left(r^{2}=0.0514, p<0.001\right)$. Sewage $N$ input in the Pamba catchment was almost an order of magnitude higher than calculated by the NEWS DON model (Fig. 5b) and exhibited a significant positive correlation with the population density $\left(r^{2}=0.722, p<0.001\right)$ and with the DON yield $\left(r^{2}=0.840\right.$, $p<0.001$ ). When excluding the Pamba data, sewage $\mathrm{N}$ inputs from other catchments 15 were weakly correlated with both the population density $\left(r^{2}=0.366, p<0.001\right)$ and DON yield $\left(r^{2}=0.0376, p<0.001\right)$. The NEWS DON model suggests that the diffuse anthropogenic source, i.e. from agricultural fields accounts for $11 \%$, while the point source, i.e. from sewage accounts for $3 \%$ of DON, respectively (Fig. 6). For the Pamba River catchment it is concluded that the high population density and associated human activities together with the lack of infrastructure for domestic waste disposal in the settlement region as well as from the unique Sabarimala pilgrimage are major factors for the extremely high DON yield.

We quantified the inputs of DON in the Pamba catchment from the pilgrim activity, agriculture and sewage effluents (Table 3). As discussed before a DON input of $25606 \mathrm{~kg} \mathrm{ha}^{-1}$ was calculated from the $10 \mathrm{~km}^{2}$ temple area and when normalized to the whole catchment, the input from the pilgrim activity amounted to $271 \mathrm{~kg} \mathrm{ha}^{-1} \mathrm{yr}^{-1}$. It comprised of $53 \%$ of the total DON inputs and $36 \%$ of the total DON yield for the Pamba catchment. Domestic sewage $\mathrm{N}$ inputs and urea fertilizer amounted to 26 and

Extreme dissolved organic nitrogen

fluxes

Elizabeth David and T. C. Jennerjahn

Title Page

Abstract Introduction

Conclusions

Tables References Figures

14

4

Back

Full Screen / Esc

Printer-friendly Version

Interactive Discussion $\rightarrow$

ose 
$<1 \mathrm{kgha}^{-1} \mathrm{yr}^{-1}$ resulting in 3 and $<1 \%$ of the total catchment yield, respectively. Therefore, inputs from all the above mentioned absolute sources made up to $40 \%$ of the total DON yield in the Pamba catchment (Table 3).

The major potential DON input quantified for the Pamba River is the $\mathrm{N}$ leaching loss 5 via livestock excretion. $148 \mathrm{~kg} \mathrm{ha}^{-1} \mathrm{yr}^{-1}$ stem from this source and made up the second largest DON input (29\%) after the pilgrim activity (53\%). It amounts to $20 \%$ of the total DON yield. Atmospheric organic $\mathrm{N}$ deposition in the Pamba catchment amounted to $5 \mathrm{kgha}^{-1} \mathrm{yr}^{-1}$ and made up $1 \%$ of the total catchment yield in the Pamba River. The other sources such as precipitation, throughfall, soil solution and BNF-agr contribute $102 \%$ each to the total Pamba River DON yield. The abovementioned DON sources together made up $29 \%$ of the total DON yield (Table 3 ) and contribute to a significant amount to the extremely high DON flux in the Pamba catchment. The total DON inputs from all sources amounted to $514 \mathrm{~kg} \mathrm{ha}^{-1} \mathrm{yr}^{-1}$ (range 477 to $752 \mathrm{~kg} \mathrm{ha}^{-1} \mathrm{yr}^{-1}$ ) and account for $69 \%$ (69 to $101 \%$ ) of the total measured DON in the Pamba catchment.

15 The unaccounted $31 \%$ are probably the result of (i) uncertainties in estimated terms for which no field data are available and (ii) missing data from regions with comparable environmental settings even not allowing for an estimate. For example, this is the case for BNF in the forest region and root exudation from inorganic fertilizer application in the agricultural land use area.

\section{Summary and conclusions}

Anthropogenic factors like the high population density, sewage disposal and other activities such as agriculture and livestock farming are responsible for the global maximum DON concentrations and fluxes measured in the Pamba River. In contrast to many other rivers, DON not only is the dominant form of $\mathrm{N}$, but accounts for $99 \%$ of the 25 TDN pool in the Pamba River. A specific cause-effect relationship was identified in the Pamba catchment by quantifying the DON fluxes from respective land use segments. The unique Sabarimala pilgrimage was the major reason of the extreme DON load and

Extreme dissolved organic nitrogen

fluxes

. Elizabeth David and T. C. Jennerjahn

Title Page

Abstract Introduction

Conclusions

Tables

References

Figures

14

4

Back

Full Screen / Esc

Printer-friendly Version

Interactive Discussion
$>$ I

Close 
yield in the Pamba River and is due to the lack of infrastructure for sanitation and waste disposal. In the Pamba River, the high nutrient load during the pilgrim event can be reduced to a major extent if there were sufficient toilets to suffice the need of the huge number of pilgrims visiting the temple.

5 A high threat to human water security and river biodiversity are a major challenge in the densely populated regions of the poor world countries, particularly in South and Southeast Asia and parts of Africa. This is because of the lack of investments in technology for clean drinking water and sanitation (Vörösmarty et al., 2010). From our study it is evident that the lack of technological investments not only affects the drinking water 10 and river biodiversity, but also has a huge impact on the riverine nutrient concentrations. Therefore, the DON derived from sewage can be a major problem to the coastal waters rather than DIN in densely populated river catchments. Our results suggest that installation of adequate sanitation measures for waste disposal and treatment together with improved agricultural and animal management practices, could strongly reduce the anthropogenic $\mathrm{N}$ input into the Pamba River. Our study also underscores the need for more regional scale quantitative studies that assess the effects of anthropogenic activities on riverine DON fluxes in tropical regions in order to improve water quality management and nitrogen budget calculations.

Acknowledgements. We thank Srikumar Chattopadhyay and Mahamaya Chattopadhyay, Sci20 thists, Centre for Earth Science Studies (CESS), Kerala, India for the enormous help during the course of the study. We thank Aneesh R, Arun R, Lijith P, Resmi Sajan, Vandana M of CESS and Tz-Ching Yeh for the help during field work and map preparations. Thanks to Matthias Birkicht for the assistance in the laboratory at the ZMT. Special thanks to Ulrike Machulik for analyzing the samples in the Institute of Biogeochemistry and Marine Chemistry, University of Hamburg. Financial support by the ZMT and the German Academic Exchange Service (DAAD) is gratefully acknowledged.
BGD

10, 16137-16171, 2013

Extreme dissolved

organic nitrogen

fluxes

. Elizabeth David and

T. C. Jennerjahn

Title Page

Abstract

Introduction

Conclusions

Tables

References

Figures

14

4

Back

Full Screen / Esc

Printer-friendly Version

Interactive Discussion 


\section{References}

Bhardwaj, R.: Water quality monitoring in India-achievements and constraints, IWG-Env, International Work Session on Water Statistics, Vienna, 1-12, 2005.

Borbor-Cordova, M. J., Boyer, E. W., McDowell, W. H., and Hall, C. A.: Nitrogen and phosphorus budgets for a tropical watershed impacted by agricultural land use: Guayas, Ecuador, Biogeochemistry, 79, 135-161, 2006.

Bouwman, A. F., Van Drecht, G., Knoop, J. M., Beusen, A. H. W., and Meinardi, C. R.: Exploring changes in river nitrogen export to the world's oceans, Global Biogeochem. Cy., 19, GB1002, doi:10.1029/2004GB002314, 2005.

10 Boyer, E. W., Howarth, R. W., Galloway, J. N., Dentener, F. J., Green, P. A., and Vörösmarty, C. J.: Riverine nitrogen export from the continents to the coasts, Global Biogeochem.Cy., 20, GB1S91, doi:10.1029/2005GB002537, 2006.

Bristow, A. W., Whitehead, D. C., and Cockburn, J. E.: Nitrogenous constituents in the urine of cattle, sheep and goats, J. Sci. Food Agr., 59, 387-394, doi:10.1002/jsfa.2740590316, 1992.

15 BusinessLine: Medical and sanitary facilities at Sabaraimala "woefully inadequate", The Hindu group of Publications, 2009.

Campbell, J., Hornbeck, J., McDowell, W., Buso, D., Shanley, J., and Likens, G.: Dissolved organic nitrogen budgets for upland, forested ecosystems in New England, Biogeochemistry, 49, 123-142, doi:10.1023/a:1006383731753, 2000.

20 Census of India: Office of Registrar General \& Census Commissioner, available at: www.censusindia.gov.in, 2011.

Chattopadhyay, S. and Chattopadhyay, M.: Impact of terrain characteristics on catchment yield - a case of Kabbini River Basin, Kerala, in: Perspectives in Resource Management in Developing Countries - Land Appraisal and Development, edited by: Thakur, B., Concept's International Series in Geography, Concept Publishing Co., New Delhi, 4, 145-157, 2009.

Christou, M., Avramides, E. J., Roberts, J. P., and Jones, D. L.: Dissolved organic nitrogen in contrasting agricultural ecosystems, Soil Biol. Biochem., 37, 1560-1563, doi:10.1016/j.soilbio.2005.01.025, 2005.

Christou, M., Avramides, E. J., and Jones, D. L.: Dissolved organic nitrogen dynamics in a Mediterranean vineyard soil, Soil Biol. Biochem., 38, 2265-2277, doi:10.1016/j.soilbio.2006.01.025, 2006.
BGD

10, 16137-16171, 2013

Extreme dissolved

organic nitrogen

fluxes

S. Elizabeth David and

T. C. Jennerjahn

Title Page

Abstract

Introduction

Conclusions

Tables

References

Figures

14

4

Back

Full Screen / Esc

Printer-friendly Version

Interactive Discussion 
Clough, T. J., Ledgard, S. F., Sprosen, M. S., and Kear, M. J.: Fate of ${ }^{15} \mathrm{~N}$ labelled urine on four soil types, Plant Soil, 199, 195-203, doi:10.1023/a:1004361009708, 1998.

Cole, J., Peierls, B., Caraco, N., and Pace, M.: Nitrogen loading of rivers as a human-driven process, in: Humans as Components of Ecosystems, edited by: McDonnell, M. and Pickett, S. A., Springer, New York, 141-157, 1993.

Elizabeth David, S., Chattopadhyay, M., Chattopadhyay, S., and Jennerjahn, T. C.: Sci. Total Environ., in review, 2013.

Fang, Y. T., Gundersen, P., Mo, J. M., and Zhu, W. X.: Input and output of dissolved organic and inorganic nitrogen in subtropical forests of South China under high air pollution, Biogeosciences, 5, 339-352, doi:10.5194/bg-5-339-2008, 2008.

Filoso, S., Martinelli, L., Williams, M., Lara, L., Krusche, A., Victoria Ballester, M., Victoria, R., and de Camargo, P.: Land use and nitrogen export in the Piracicaba River basin, Southeast Brazil, Biogeochemistry, 65, 275-294, doi:10.1023/a:1026259929269, 2003.

Filoso, S., Martinelli, L., Howarth, R., Boyer, E., and Dentener, F.: Human activities changing the nitrogen cycle in Brazil, in: Nitrogen Cycling in the Americas: Natural and Anthropogenic Influences and Controls, edited by: Martinelli, L. and Howarth, R., Springer, the Netherlands, 61-89, 2006.

Galloway, J. N., Dentener, F. J., Capone, D. G., Boyer, E. W., Howarth, R. W., Seitzinger, S. P., Asner, G. P., Cleveland, C. C., Green, P. A., Holland, E. A., Karl, D. M., Michaels, A. F., Porter, J. H., Townsend, A. R., and Vöosmarty, C. J.: Nitrogen cycles: past, present, and future, Biogeochemistry, 70, 153-226, doi:10.1007/s10533-004-0370-0, 2004.

Galloway, J. N., Townsend, A. R., Erisman, J. W., Bekunda, M., Cai, Z., Freney, J. R., Martinelli, L. A., Seitzinger, S. P., and Sutton, M. A.: Transformation of the nitrogen cycle: recent trends, questions, and potential solutions, Science, 320, 889-892, doi:10.1126/science.1136674, 2008.

Glibert, P., Harrison, J., Heil, C., and Seitzinger, S.: Escalating worldwide use of urea a global change contributing to coastal eutrophication, Biogeochemistry, 77, 441-463, doi:10.1007/s10533-005-3070-5, 2006.

Grasshoff, K., Kremling, K., and Ehrhardt, M. (Eds.): Methods of Seawater Analysis, 3rd edn., Wiley-VCH, Weinheim, 1999.

Hanson, A. M. and Lee, G. F.: Forms of organic nitrogen in domestic wastewater, J. Water Pollut. Control Fed., 43, 2271-2279, http://www.jstor.org/stable/25037233, 1971.
BGD

$10,16137-16171,2013$

Extreme dissolved

organic nitrogen

fluxes

S. Elizabeth David and

T. C. Jennerjahn

Title Page

Abstract

Introduction

Conclusions

Tables

References

Figures

14

4

Back

Close

Full Screen / Esc

Printer-friendly Version

Interactive Discussion 
Harrison, J. A., Caraco, N., and Seitzinger, S. P.: Global patterns and sources of dissolved organic matter export to the coastal zone: Results from a spatially explicit, global model, Global Biogeochem. Cy., 19, doi:10.1029/2005gb002480, 2005.

Haynes, R. J. and Williams, P. H.: Nutrient cycling and soil fertility in the grazed pasture ecosystem, in: Advances in Agronomy, edited by: Donald, L. S., Academic Press, 119-199, 1993.

Hoogendoorn, C. J., Betteridge, K., Costall, D. A., and Ledgard, S. F.: Nitrogen concentration in the urine of cattle, sheep and deer grazing a common ryegrass/cocksfoot/white clover pasture, New Zeal. J. Agr. Res., 53, 235-243, doi:10.1080/00288233.2010.499899, 2010.

Jordan, T. E. and Weller, D. E.: Human contributions to terrestrial nitrogen flux, BioScience, 46, 655-664, doi:10.2307/1312895, 1996.

Lorite-Herrera, M. and Jiménez-Espinosa, R.: Impact of agricultural activity and geologic controls on groundwater quality of the alluvial aquifer of the Guadalquivir River (province of Jaén, Spain): a case study, Environ. Geol., 54, 1391-1402, doi:10.1007/s00254-007-09206, 2008.

Lorite-Herrera, M., Hiscock, K., and Jiménez-Espinosa, R.: Distribution of dissolved inorganic and organic nitrogen in river water and groundwater in an agriculturally-dominated catchment, south-east Spain, Water Air Soil Pollut., 198, 335-346, doi:10.1007/s11270-008-9849y, 2009.

Lovett, G. M., Weathers, K. C., and Sobczak, W. V.: Nitrogen saturation and retention in forested watersheds of the Catskill Mountains, New York, Ecol. Appl., 10, 73-84, 2000.

Martinelli, L., Coletta, L., Ravagnani, E., Camargo, P., Ometto, J., Filoso, S., and Victoria, R.: Dissolved nitrogen in rivers: comparing pristine and impacted regions of Brazil, Braz. J. Biol., 70, 709-722, 2010.

Neff, J. C., Holland, E. A., Dentener, F. J., McDowell, W. H., and Russell, K. M.: The origin, composition and rates of organic nitrogen deposition: a missing piece of the nitrogen cycle?, Biogeochemistry, 57, 99-136, 2002.

Painter, H. A. and Viney, M.: Composition of a domestic sewage, J. Biochem. Microbiol., 1, 143-162, doi:10.1002/jbmte.390010203, 1959.

Pellerin, B., Kaushal, S., and McDowell, W.: Does anthropogenic nitrogen enrichment increase organic nitrogen concentrations in runoff from forested and human-dominated watersheds?, Ecosystems, 9, 852-864, doi:10.1007/s10021-006-0076-3, 2006.

Perakis, S. S. and Hedin, L. O.: Nitrogen loss from unpolluted South American forests mainly via dissolved organic compounds, Nature, 415, 416-419, 2002.
BGD

$10,16137-16171,2013$

Extreme dissolved

organic nitrogen

fluxes

. Elizabeth David and

T. C. Jennerjahn

Title Page

Abstract

Introduction

Conclusions

Tables

References

Figures

14

4

Back

Close

Full Screen / Esc

Printer-friendly Version

Interactive Discussion 
Prasad, V. K., Badarinath, K. V. S., Yonemura, S., and Tsuruta, H.: Regional inventory of soil surface nitrogen balances in Indian agriculture (2000-2001), J. Environ. Manage., 73, 209218, doi:10.1016/j.jenvman.2004.06.013, 2004.

Rabalais, N. N.: Nitrogen in aquatic ecosystems, AMBIO, 31, 102-112, doi:10.1579/0044-744731.2.102, 2002.

Schwendenmann, L. and Veldkamp, E.: The role of dissolved organic carbon, dissolved organic nitrogen, and dissolved inorganic nitrogen in a tropical wet forest ecosystem, Ecosystems, 8, 339-351, doi:10.1007/s10021-003-0088-1, 2005.

Seitzinger, S. and Sanders, R.: Contribution of dissolved organic nitrogen from rivers to estuarine eutrophication, Mar. Ecol.-Prog. Ser., 159, 1-12, 1997.

Seitzinger, S. P., Sanders, R., and Styles, R.: Bioavailability of DON from natural and anthropogenic sources to estuarine plankton, Limnol. Oceanogr., 47, 353-366, 2002.

Seitzinger, S. P., Hartnett, H., Lauck, R., Mazurek, M., Minegishi, T., Spyres, G., and Styles, R.: Molecular-level chemical characterization and bioavailability of dissolved organic matter in stream water using electrospray-ionization mass spectrometry, Limnol. Oceanogr., 50, 1-12, 2005.

Shand, C. A. and Coutts, G.: The effects of sheep faeces on soil solution composition, Plant Soil, 285, 135-148, doi:10.1007/s11104-006-0065-5, 2006.

Turner, R. E., Rabalais, N. N., Justic, D., and Dortch, Q.: Global patterns of dissolved N, P and

20 Si in large rivers, Biogeochemistry, 64, 297-317, doi:10.1023/a:1024960007569, 2003.

Tyagi, V. K., Bhatia, A., Gaur, R. Z., Khan, A. A., Ali, M., Khursheed, A., Kazmi, A. A., and Lo, S.-L.: Impairment in water quality of Ganges River and consequential health risks on account of mass ritualistic bathing, Desal. Water Treatm., 51, 2121-2129, doi:10.1080/19443994.2013.734677, 2012.

van Kessel, C., Clough, T., and van Groenigen, J. W.: Dissolved organic nitrogen: an overlooked pathway of nitrogen loss from agricultural systems?, J. Environ. Qual., 38, 393-401, doi:10.2134/jeq2008.0277, 2009.

Vitousek, P. M., Aber, J. D., Howarth, R. W., Likens, G. E., Matson, P. A., Schindler, D. W., Schlesinger, W. H., and Tilman, D. G.: Human alterations of the global nitrogen cycle: sources 30 and consequences, Ecol. Appl., 7, 737-750, 1997.

Vorosmarty, C. J., McIntyre, P. B., Gessner, M. O., Dudgeon, D., Prusevich, A., Green, P., Glidden, S., Bunn, S. E., Sullivan, C. A., Liermann, C. R., and Davies, P. M.: Global threats to human water security and river biodiversity, Nature, 467, 555-561, 2010.

Extreme dissolved organic nitrogen

fluxes

S. Elizabeth David and T. C. Jennerjahn

Title Page

Abstract Introduction

Conclusions

Tables References Figures

14

4

Back

Close

Full Screen / Esc

Printer-friendly Version

Interactive Discussion 
Watson, C. J., Jordan, C., Lennox, S. D., Smith, R. V., and Steen, R. W. J.: Organic nitrogen in drainage water from grassland in Northern Ireland, J. Environ. Qual., 29, 1233-1238, doi:10.2134/jeq2000.00472425002900040029x, 2000.

Westerhoff, P. and Mash, H.: Dissolved organic nitrogen in drinking water supplies: a review, Aqua, 51, 415-448, 2002.

WHO/UNICEF: Progress on Sanitation and Drinking-Water: 2010 Update, Joint Monitoring Programme for Water Supply and Sanitation (World Health Organisation/UNICEF, 2010), 2010.

Extreme dissolved

organic nitrogen

fluxes

S. Elizabeth David and

T. C. Jennerjahn

Title Page

Abstract Introduction

Conclusions

References

Tables

Figures

14

$>$ I

4

Back

Close

Full Screen / Esc

Printer-friendly Version

Interactive Discussion 
Table 1. Land use categories in the Pamba catchment in 2010.

\begin{tabular}{lrr}
\hline Landuse & Area in $\mathrm{km}^{2}$ & \% of total area \\
\hline Forest & 977.6 & 43.7 \\
Settlement with mixed tree crops (SMT) & 318.9 & 14.3 \\
Rubber & 247.6 & 11.1 \\
Paddy & 210.4 & 9.4 \\
Water body & 139.4 & 6.2 \\
Fallow land & 132.9 & 5.9 \\
Settlements & 88.2 & 3.9 \\
Tea & 33.7 & 1.5 \\
Marshy land & 22.5 & 1.0 \\
Open scrub & 20.5 & 0.9 \\
Reservoir & 20.0 & 0.9 \\
Eucalyptus & 16.4 & 0.7 \\
Cardamom & 7.7 & 0.3 \\
\hline Total catchment area & \multicolumn{2}{c}{2235} \\
\hline
\end{tabular}

10, 16137-16171, 2013

Extreme dissolved organic nitrogen

fluxes

S. Elizabeth David and

T. C. Jennerjahn

Title Page

Abstract

Introduction

Conclusions References

Tables

Figures

14

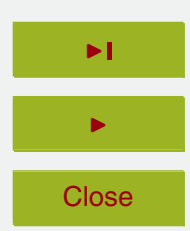

Back

Close

Full Screen / Esc

Printer-friendly Version

Interactive Discussion 
Table 2. Segment wise annual DON load and yield for the Pamba River.

\begin{tabular}{lllrrrrr}
\hline Segment & $\begin{array}{l}\text { Area } \\
\left(\mathrm{km}^{2}\right)\end{array}$ & Dominant land use & $\begin{array}{r}\text { Segment } \\
\text { area }(\%)\end{array}$ & $\begin{array}{r}\text { Discharge } \\
\left(\mathrm{km}^{3} \mathrm{yr}^{-1}\right)\end{array}$ & $\begin{array}{r}\text { Population density } \\
(\text { inhabitants km }\end{array}$ & $\begin{array}{r}\text { DON load } \\
\left(\mathrm{tyr}^{-1}\right)\end{array}$ & $\begin{array}{r}\text { DON yield } \\
\left(\mathrm{kg} \mathrm{ha}^{-1} \mathrm{yr}^{-1}\right)\end{array}$ \\
\hline I & 249.6 & Forest & 11 & 0.4 & $<1$ & 2244 & 90 \\
II & 219.7 & Temple, Forest & 10 & 0.4 & $<1$ & 43398 & 1976 \\
III & 359.5 & Forest, Plantation & 16 & 0.6 & 78 & 66982 & 1863 \\
IV & 621.1 & Forest, Rubber, Settlement & 28 & 1.1 & 148 & 84929 & 1367 \\
V & 110.1 & Rubber, Smt & 5 & 0.2 & 583 & 20017 & 1818 \\
VI & 159.8 & Smt & 7 & 0.3 & 894 & 21925 & 1372 \\
VII & 175.3 & Smt, Paddy & 8 & 0.3 & 1313 & 13421 & 765 \\
VIII & 339.8 & Paddy, Smt (Wetland) & 15 & 0.6 & 1034 & 22546 & 663 \\
\hline
\end{tabular}

10, 16137-16171, 2013

Extreme dissolved

organic nitrogen

fluxes

S. Elizabeth David and

T. C. Jennerjahn

Title Page

Abstract

Introduction

Conclusions

References

Tables

Figures

14

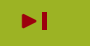

4

Back

Close

Full Screen / Esc

Printer-friendly Version

Interactive Discussion 
Table 3. Dissolved organic nitrogen inputs into the Pamba River.

\begin{tabular}{lrrrl}
\hline & $\begin{array}{r}\text { DON } \\
\text { Sources }\end{array}$ & $\begin{array}{r}\% \text { of the } \\
\text { total input }\end{array}$ & $\begin{array}{r}\text { \% of the } \\
\text { total DON yield }\end{array}$ & References \\
\hline Pilgrims & 271 & 53 & 36 & This study \\
Domestic sewage & 26 & 5 & 3 & This study \\
Urea & $<1$ & $<1$ & $<1$ & This study \\
Livestock excretion & 148 & 29 & 20 & Prasad et al. (2004) \\
Precipitation & 18 & 3 & 2 & Fang et al. (2008) \\
Throughfall (average) & 17 & 3 & 2 & Fang et al. (2008) \\
BNF-agr & 17 & 3 & 2 & Prasad et al. (2004) \\
Soil solution (average) & 12 & 2 & 2 & Fang et al. (2008) \\
Atmospheric organic N & 5 & 1 & 1 & Neff et al. (2002) \\
(AON) deposition & & & & \\
\hline Total inputs $\left(\mathrm{kg} \mathrm{ha}^{-1} \mathrm{yr}^{-1}\right)$ & $514\left(477 \mathrm{to}^{-1} \mathrm{~kg} \mathrm{~kg} \mathrm{ha}^{-1} \mathrm{yr}^{-1}\right)$ & & \\
\hline
\end{tabular}

BGD

10, 16137-16171, 2013

Extreme dissolved

organic nitrogen

fluxes

S. Elizabeth David and

T. C. Jennerjahn

Title Page

Abstract

Introduction

Conclusions

References

Tables

Figures

14

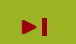

4

Back

Close

Full Screen / Esc

Printer-friendly Version

Interactive Discussion 


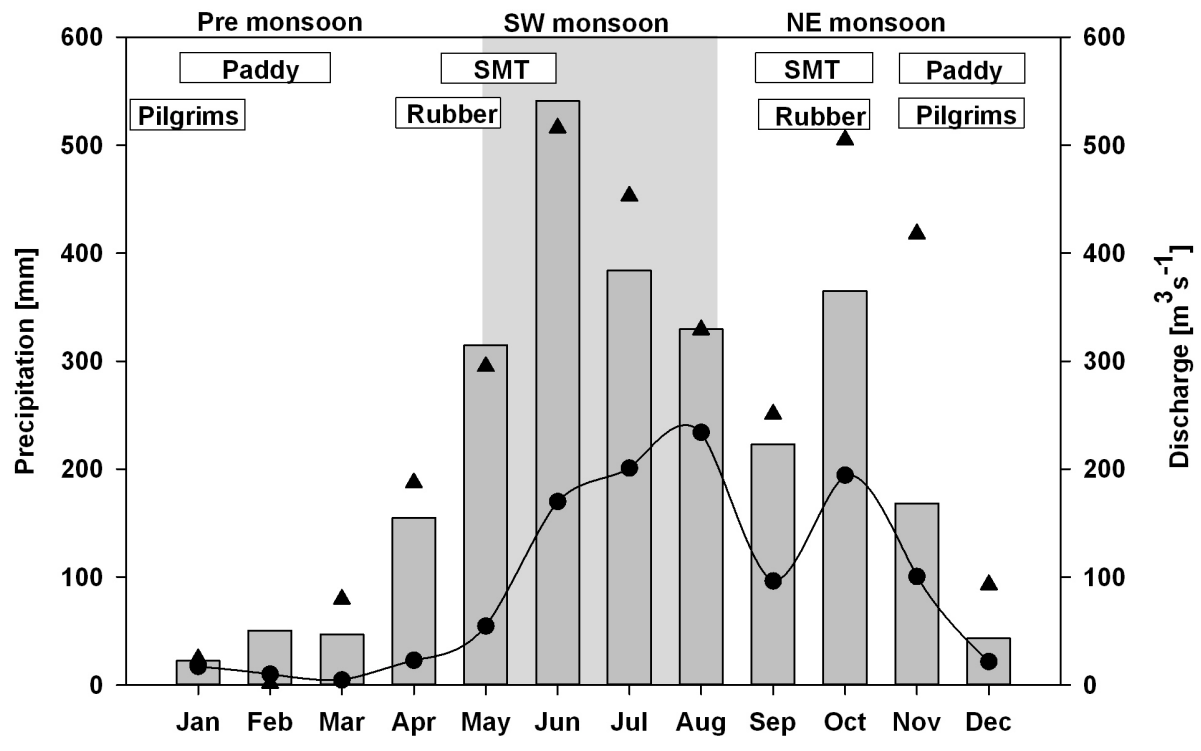

Fig. 1. Hydrological cycle, fertilization and pilgrim events in the Pamba basin. Average precipitation (grey bars) and discharge (filled circles, solid lines) pattern in Alappuzha and Pathanamthitta districts during the period 2000-2005. Precipitation during 2010 campain (filled triangles).

\section{BGD}

\section{$10,16137-16171,2013$}

\section{Extreme dissolved \\ organic nitrogen \\ fluxes \\ S. Elizabeth David and \\ T. C. Jennerjahn \\ Title Page \\ Abstract \\ Introduction}

Conclusions

References

Tables

Figures

14

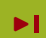

4

Back

Close

\section{Full Screen / Esc}

Printer-friendly Version 


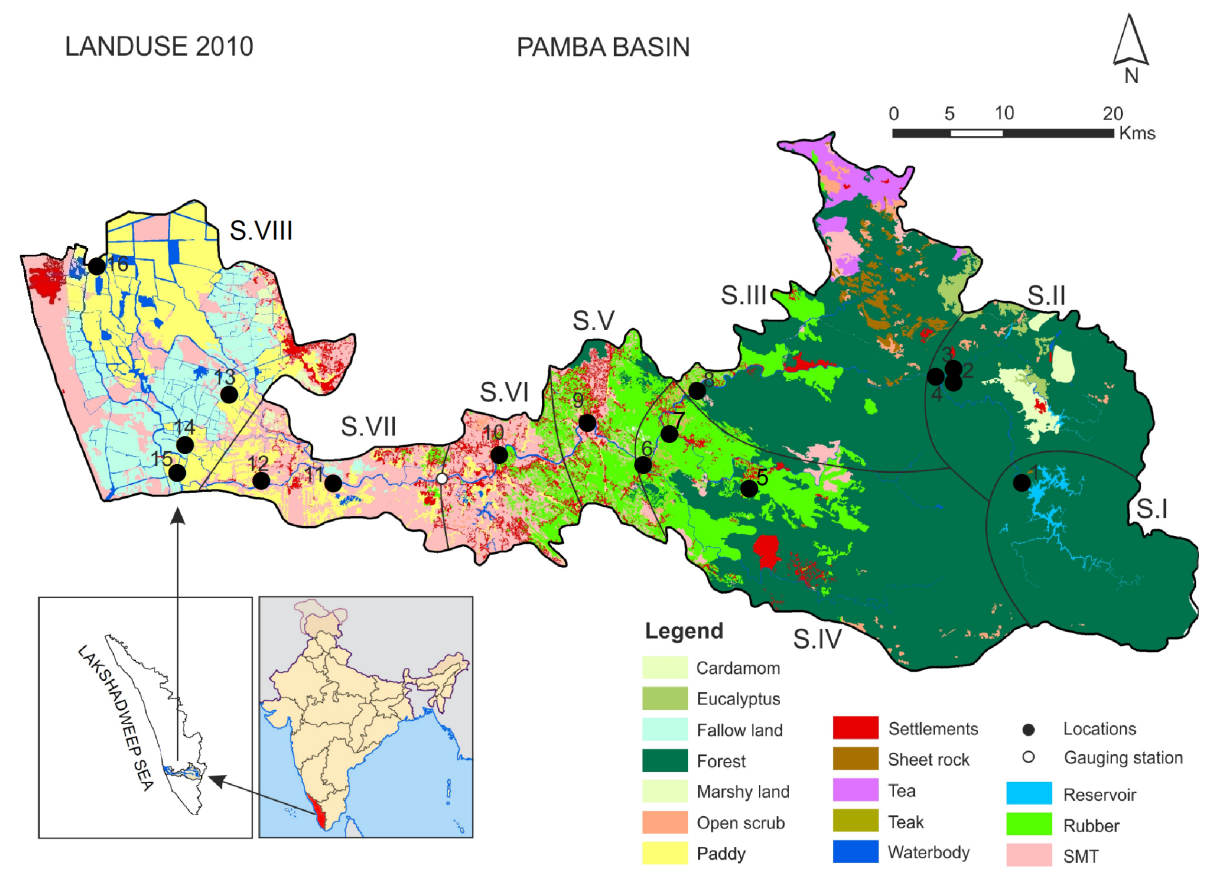

Fig. 2. Land use map of the Pamba River including sampling locations and segments.

Extreme dissolved organic nitrogen fluxes

S. Elizabeth David and T. C. Jennerjahn

Title Page

Abstract Introduction

Conclusions References

Tables Figures

14 $\triangleleft$

Back

Close

Full Screen / Esc

Printer-friendly Version

Interactive Discussion 


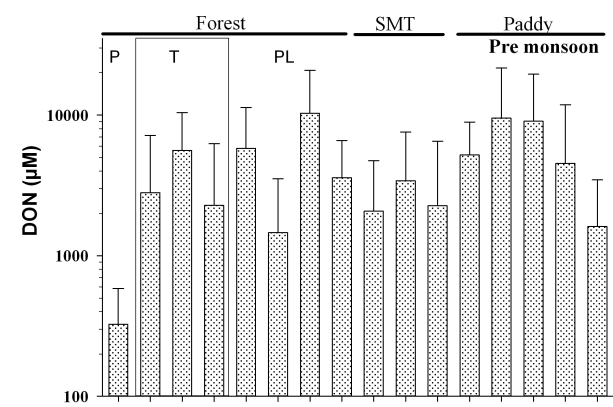

BGD

10, 16137-16171, 2013

Extreme dissolved organic nitrogen

fluxes

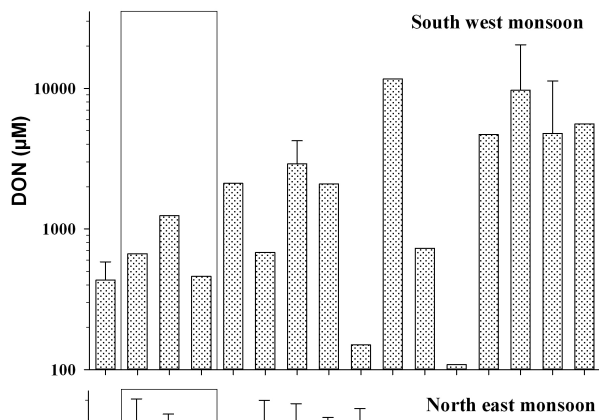

S. Elizabeth David and

T. C. Jennerjahn

Title Page

Abstract

Introduction

Conclusions

References

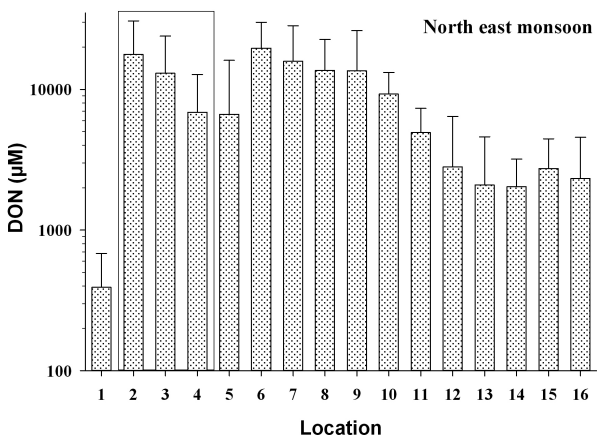

Tables

Figures

14

$>$ I

4

Back

Close

Full Screen / Esc

Printer-friendly Version

Fig. 3. Dissolved organic nitrogen concentrations during the premonsoon, southwest monsoon and northeast monsoon seasons in the Pamba catchment. 


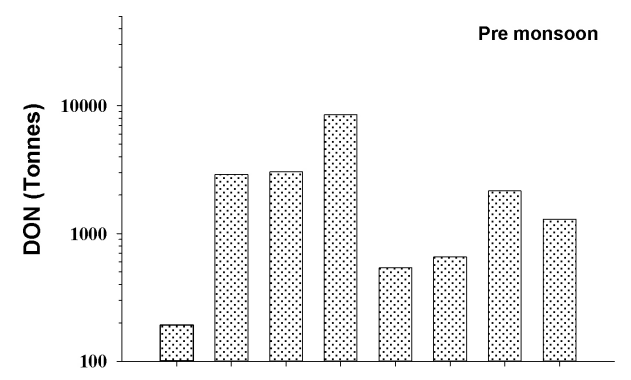

\section{BGD}

\section{0, 16137-16171, 2013}

\section{Extreme dissolved} organic nitrogen

fluxes
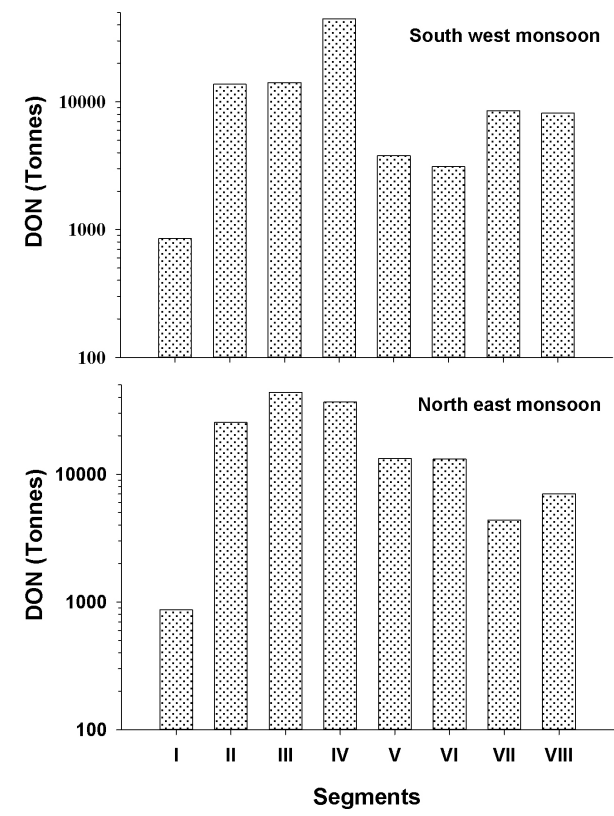

S. Elizabeth David and

T. C. Jennerjahn

Title Page

Abstract

Introduction

Conclusions

References

Tables

Figures

14

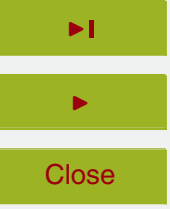

Back

Full Screen / Esc

Printer-friendly Version

Fig. 4. Dissolved organic nitrogen loads during the premonsoon, southwest monsoon and northeast monsoon seasons in the Pamba catchment.

Interactive Discussion 


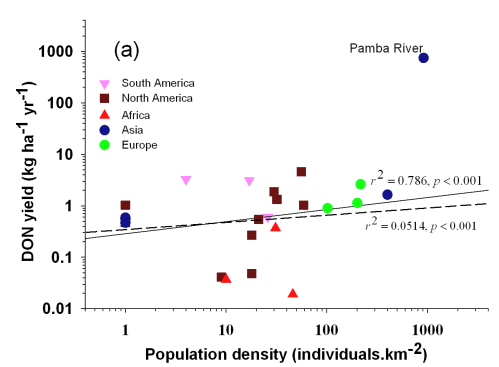

BGD

10, 16137-16171, 2013

Extreme dissolved

organic nitrogen

fluxes

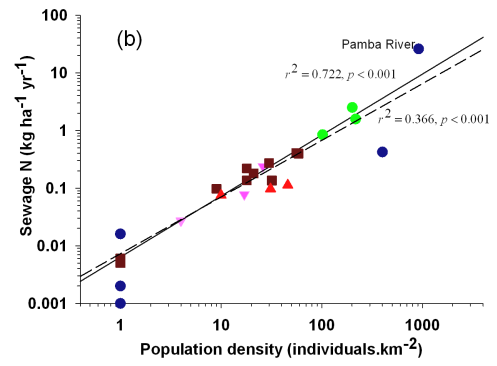

S. Elizabeth David and

T. C. Jennerjahn

Title Page

Abstract

Introduction

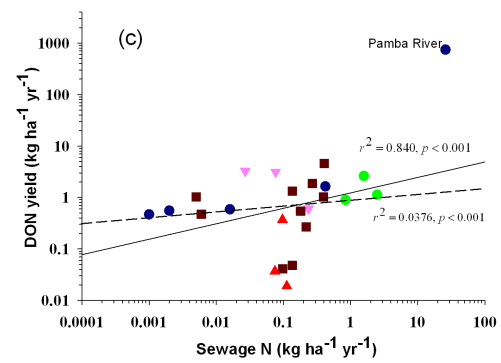

Conclusions

References

Tables

Figures

14

I

4

Back

Close

Full Screen / Esc

Fig. 5. Relationship between (a) population density and DON yield; (b) population density and sewage input; (c) sewage input and DON yield. Data for the comparison are taken from the NEWS (Global Nutrient export from Watersheds) DON model by Harrison et al. (2005). The solid line denotes the linear regression line for all data points, the dashed line denotes it for all data points excluding the Pamba River.

Printer-friendly Version

Interactive Discussion 


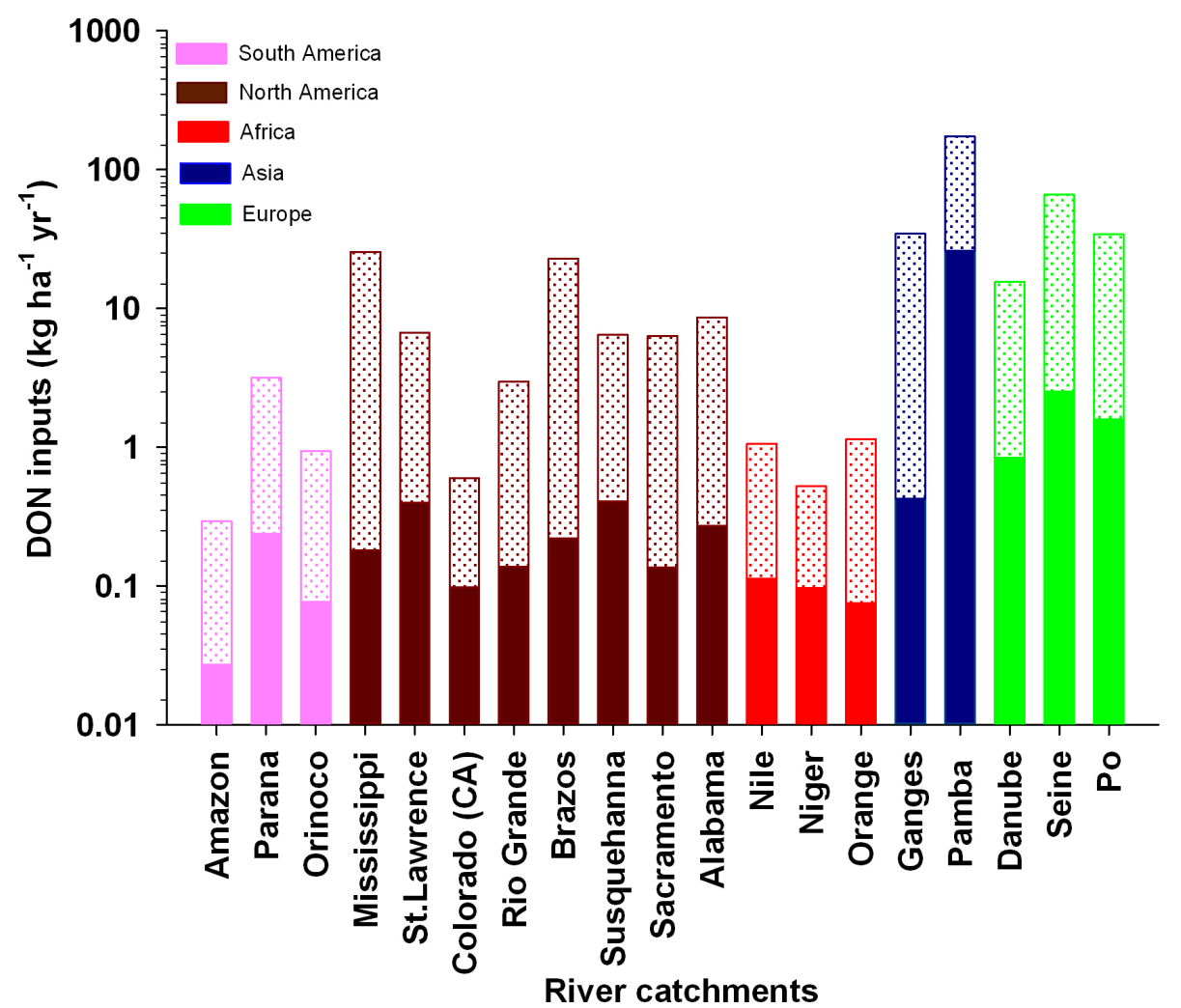

Fig. 6. Comparison of DON inputs in the Pamba Riverwith other world rivers. Input from sewage (filled bars) and manure (dotted bars). Data for other rivers are from Harrison et al. (2005).
BGD

10, 16137-16171, 2013

Extreme dissolved

organic nitrogen

fluxes

S. Elizabeth David and

T. C. Jennerjahn

Title Page

Abstract

Introduction

Conclusions

References

Tables

Figures

14

$>$ I

4

Back

Close

\section{Full Screen / Esc}

Printer-friendly Version

Interactive Discussion 